\title{
Family Reunification in Albania: A Comparative Study in the Context of Albanian Integration in the EU
}

\author{
Erjona Canaj \\ PhD, Lector at the European University of Tirana \\ Cel: + 355686031506/erjona.canaj@uet.edu.a \\ Arjan Vasjari \\ European University of Tirana
}

\section{Doi:10.5901/mjss.2013.v4n6p681}

\begin{abstract}
:
Family Reunification is a necessary way of making family life possible. It is a fundamental right and it is a social right. This article examines Albanian legislation on family reunification. The purpose of the Albanian new legislation is to create a complete legal framework according to the European Union rules on family reunification. The aim of this study is to analyze, under Migration and Asylum Legislation of the Republic of Albania, the procedures, the conditions and the beneficiaries of family reunification of migrants and refugees in the territory of Albania. It will analyze the definition of the family, the conditions of entry and stay and the rights conferred on family members. We argue that the issue of family reunification is not the heart of immigration policy. Albanian legislation is now presented more "in line" with the European standards even that the progress has been slower and less substantial than expected. Moreover, the level of protection of family life in these instruments should be significantly higher than the present one. Many flexible elements should be introduced to facilitate the process of family reunification and to force the protection of the rights of family members.
\end{abstract}

Key words: family reunification, Albanian immigration legislation, sponsor, family member, formal and material conditions.

\section{General Framework}

Family Reunification is a necessary way of making family life possible. It helps to create socio-cultural stability facilitating the integration of the migrant in the territory of the host State. Family reunification is a recognized reason for immigration in many countries because of the presence of one or more family members in a certain country, therefore, enabling the rest of the family to immigrate to that country as well. In this context, family reunification is a fundamental right and a social right as well (Sesta 2007: 370; Rossi 1994: 98; Hailbronner 2007: 320). This is an important right in the general context of free movement and migration (Ferrari Bravo and Moavero Milanesi 2000: 275).

The aim of this study is to stimulate public discussion on family reunification in Albania, given that this country has adopted new legislation in this field, in order to obtain an initial impression of this legislation, to compare and to analyze it in the context of the process of membership in the European Union. This process for Albania started immediately after the fall of the totalitarian communist system (1991) and it has been a political and historical mission. On May 1992, Albania signed the Trade and Co-operation Agreement with the EC and in June 2006 the country completed in Luxemburg a long cycle of negotiations regarding the signature of the Stabilization and Association Agreement (SAA) with the European Union ${ }^{1}$. Almost six years after the signature and the ratification of the SAA by all Member States, European Integration continues to be the paramount priority of the Republic of Albania.

The integration process is the main driving force for all reforms. Remarkable progress has been achieved and many efforts have been made on the way to streamlining country's policy towards a more rapid accommodation of EU policies and legislation. European Union is a space of common democratic values, composed of freedom and tolerance

1 On June 12 2006 Albania signed the Stabilisation and Association Agreement (SAA) at the General Affairs and External Relations Council in Luxemburg and, on December, the Interim Agreement enters into force. In January 2009, the Procedures of ratification of the Stabilisation and Association Agreement between the Republic of Albania and European Union and its Member States are completed by all Member States. The documents are available at www.europa.eu and www.mie.gov.al. See The Pre-Accession Dialogue EU-Albania, Tiranë, 2009, 8-86. 
while it is becoming the most important partner for Albania. EU integration is a very demanding process and requires full commitment by both the Albanian government: stable institutions that guarantee democracy, a functional market economy, the ability to adopt the membership obligations, the guarantee of the rule of law and, in particular, the respect of human rights.

Thus, among other reforms in several fields, Albania has adopted, in this context, the new legislation on migration and has adopted new rules on family reunification. The purpose of the Albanian new legislation is to create a complete legal framework, according to the European Union rules on family reunification, and in particular in conformity with directive 2003/86/EC which regulates family reunification of migrants (workers, self-employers etc.) within the territory of the European Union. The intent is to examine the conditions, the beneficiaries and the procedures of family reunification of migrants and refugees that are in Albanian territory, in particular the Albanian Migration and Asylum Legislation, Law No. 9959/2008 "On Foreigners" and Law No. 8432/1998 on Asylum in the Republic of Albania (Ikonomi 2011: 129). In this perspective, we will use the term "sponsor" for all migrants (workers, self-employers, refugees etc.) that are lawfully residing and are entitled to the right of family reunification in the territory of the Republic of Albania.

\section{Family Reunification in the European Union}

The list of legal instruments being in one way or another linked to the issue of family reunification is considerably large because of the great number of aspects that affect family life (Peers 2005: 265-266). Just to mention a few, family life involves, at a basic definition level, the composition of the family, but may also involve the rights these family members may invoke (access to the labor market, schooling, social security etc.) and the rights they may still claim after the family relationship has come to an end (Groenendijk 2004: 119). The right to family reunification is enshrined in many international instruments. We can mention here the Universal Declaration of Human Rights (Articles 12 and 16); UN International Covenant on Civil and Political Rights (Articles 17 and 23); UN International Covenant on Economic, Social and Cultural Rights (Article 2); International Convention on the Rights of the Child (Articles 9 and 10); European Convention on Human Rights (Article 8); European Social Charter (Articles 16 and 19); International Convention on the protection of the Rights of All Migrant Workers and Members of their families (Article 44); European Convention on the legal status of migrant workers (Article 12); the Charter of Fundamental Rights of the European Union (Article 7), etc (Colacino 2004: 76). It can be said that family reunification, as a universal human rights instrument, is connected with the concept of migrant workers, in order to combat racism, xenophobia and to assure basic human rights. These international treaties were adopted mainly by ILO and the UN. Notwithstanding the unclear competence of the UN and ILO concerning the migrant workers, and moreover the vague wording of the legal instrument they have produced which normally are not even legally binding for all States - one element of these instruments is constant and clear. The right to family life and family unit is important for everybody, including migrant workers, and this has to be taken into account by the assessment of the human rights component of European Union legislation on family reunification for migrant workers (Carlier and Guild, 2006, 21; Guild 2004). At the other hand, the regional European human rights instruments do not grant a clearly defined right to family reunification for migrant workers, but allusions to the existence of such right, deriving in part from the importance of the right of family recognized by all instruments, can be inferred. The best promise for the future in this respect is in the EU Human Rights Charter, which is legally binding by the Treaty of Lisbon (2009). It actually guarantees the human right of family life and family unity to all legal residents in the European Union.

I. Family reunification for EU citizens in the European Union is a right seen as a corollary right of the provision of free movement (Giubboni and Orlandini 2007: 64; Villani 2008: 87; Ferrari Bravo and E.Moavero Milanesi, 2000: 275). Thus, family reunification of EU citizens falls under the general regime of free movement of persons (Adinolfi 2005: 69 Sesta 2007: 370) that constitutes one of the fundamental freedoms of the internal market, and comprises an area without internal frontiers in which freedom is ensured in accordance with the provisions of the Treaty (Adobati-Cimolino-PoloSantini 1999: 35; Hailbronner 2007: 322; Giubboni and G.Orlandini, 2007: 64; Villani 2008: 87). Following the introduction of citizenship of the Union, the right to move and reside in the Member State of choice has become a constitutional right flowing from the status of citizenship of the Union. The key body of relevant rules governing the free movement of persons is mainly found in Article 45 TFEU and Title IV of the European Union Treaty. The provisions of the EU Treaty related to the freedom of movement of persons are supplemented by a considerable body of Community secondary legislation, such as Regulation (EEC) No 1612/68, Directive 68/360/EEC, Directive 73/148/EEC, Council Directive 
90/365/EEC etc. One of these instruments is the directive 2004/38/EC ${ }^{2}$ of the European Parliament and the Council of April $29^{\text {th }} \mathbf{2 0 0 4}$ on the right of citizens of the Union and their family members to move and reside freely within the territory of the Member States.

This Directive lays down the conditions governing the exercise of the right of free movement and residence within the territory of Member States by the Union citizens and their family members, the right of permanent residence in the territory of the Member States for Union citizens and their family members as well as the limits placed with regard to the public policy, public security or public health. Directive 2004/38/EC summarizes in a single legal instrument the rules for the entry and residence of self-employed persons, employed persons, students, persons and families with no economic sustainability, by extending this fundamental right to all EU citizens who exercise their right to free movement and residence (Lang and Nascimbene, 2007: 4; Peers 2005: 265. The objectives of Directive no. 2004/38 reside in:

a) the establishment of the conditions in which the citizens of the European Union and their family members can freely move and settle down on the territory of the member states;

b) the right to permanent establishment in the member states, given to the citizens of the Union and to their family members;

c) the limitations of the right to free movement and of the right of residence, for public order, security or health reasons.

The right of all Union citizens to move and reside freely within the territory of the Member States, if it is to be exercised under objective conditions of freedom and dignity, is also granted to their family members, irrespective of nationality. It should be emphasized that the rights enjoyed by families due to family reunification are enjoyed as long as they have the status "family member" of a national community that has exercised the right of free movement. In this context, "family member" is considered: (a) the spouse; (b) the partner with whom the Union citizen has contracted a registered partnership, on the basis of the legislation of a Member State, if the legislation of the host Member State treats registered partnerships as equivalent to marriage and in accordance with the conditions laid down in the relevant legislation of the host Member State; (c) the direct descendants who are under the age of 21 or are dependants and those of the spouse or partner as defined in point (b); (d) the dependent direct relatives in the ascending line and those of the spouse or partner as defined in point (b). Without prejudice to any right to free movement and residence, the host Member State, in accordance with its national legislation, facilitates entry and residence for the following persons: (a) any other family members, irrespective of their nationality, not falling under the definition in point 2 of Article 2 who, in the country from which they have come, are dependants or members of the household of the Union citizen having the primary right of residence, or where serious health grounds strictly require the personal care of the family member by the Union citizen; (b) the partner with whom the Union citizen has a durable relationship, duly attested. The directive also explicitly includes the rights for family members, as part of the rights of the European citizen in respect to his family life (Iglesias Sànchez 2007: 913; Di Filippo 2008, 425). While it is true that the right of movement and residence of family members of Union citizens is not explicitly referred to by the Treaty, the right does flow from the right to preserve family unity, which is intrinsically connected with the right to the protection of family life, a fundamental right of the common constitutional traditions of the Member States, which are protected by the Community law and incorporated in the Charter of Fundamental Rights of the European Union. The human right's approach toward the family is reflected in the

\footnotetext{
2 The Directive amended Regulation (EEC) No 1612/68 on freedom of movement for workers within the Community and repealed Council Directive 68/360/EEC of 15 October 1968 on the abolition of restrictions on movement and residence within the Community for workers of Member States and their families; Council Directive 73/148/EEC of 21 May 1973 on the abolition of restrictions of movement and residence within the Community for nationals of Member States with regard to establishment and the provision of services; Council Directive 90/364/EEC of 28 June 1990 on the right of residence; Council Directive 90/365/EEC of 28 June 1990 on the right of residence for employees and self-employed persons who have ceased their occupational activity and Council Directive 93/96/EEC of 29 October 1993 on the right of residence for students. See on this argument SANNA, "La direttiva 2004/38/CE relativa al diritto dei cittadini dell'Unione e dei loro familiari di circolare e soggiornare liberamente nel territorio degli Stati membri", Rivista di diritto internazionale privato e processuale, 42/2006, 1167; MISSORICI-ROMANO, "Libertà di circolazione e soggiorno: i cittadini degli Stati terzi tra cittadinanza europea e politica delle migrazioni', Rivista internazionale dei diritti dell'uomo, 11/98, 44; GIUBBONI-ORLANDINI, La libera circolazione dei lavoratori nell'Unione europea, Bologna, 2007; LANG-NASCIMBENE, "L'attuazione in Italia della direttiva 2004/38/CE sulla libera circolazione dei cittadini dell'Unione europea", Diritto, immigrazione, cittadinanza, 2/2007, 3-10; PEERS, "Key legislative developments on migration", European Journal of Migration and Law, 2005, 265; IGLESIAS SÀNCHEZ, "Dos cuestiones suscitada por la transposizión espańola de la directiva 2004/38/CE a travès del RD 240/2007: el règimen aplicable a los ascendientes de espańoles y la extensión a las parejas registradas del concepto de "miembros de la famiglia de los ciudadanos de la Unión"' Revista de Derecho Comunitario Europeo, 2007, 913; DI FILIPPO, "La libera circolazione dei cittadini comunitari e l'ordinamento italiano: (poche) luci e (molte) ombre nell'attuazione della direttiva 2004/38", Rivista di diritto internazionale, 2008, 425.
} 
provisions of the directive which enlarges the personal scope for family reunification (Carlier and Guild, 2006: 21; Guild 2004; Costello 2009: 607; Currie, 2009: 325).

II. Family reunification of non-EU nationals has always been subject to domestic legislation which was uninfluenced by the Community law because European legislation lacked the legal acts that regulate family reunification (Guild and Niessen 2007; Guild and Harlow 2001 Groenendijk - Fernhout - Van Dam- Van Oers - Strik 2007). In the last 20 years, family reunification has been one of the main reasons of immigration to the EU. Immigration had become a central political issue in all European countries affected by it. The migration discussion was politicized and emotionalized in the 1980s, provoked by the rapidly rising immigration of refugees and asylum seekers from the 'Third World'.

At the European level, there has been a push to create a unified approach to the treatment and rights of third-country nationals that both offers protection and preserves the sovereignty of member-states to define the terms of national belonging. On May $1^{\text {st }}$ 1999, the Amsterdam Treaty entered into force, adding Head IV, "Visa, asylum, immigration and other policies related to free movement of persons", to the EC Treaty ${ }^{3}$. The new Articles 61 to 69 of the EC Treaty are designed to progressively establish an area of freedom, security and justice.

According to Article 63 (3) (a) of the EC Treaty, the Council, acting unanimously on a proposal of the Commission or at the initiative of a Member State, after consulting the European Parliament, within a period of five years from the entry into force of the Treaty of Amsterdam, shall adopt measures regarding conditions of entry and residence and standards on procedures for the issue by Member States of long-term visas and residence permits, including those for the purpose of family reunion. The European Council, at its special meeting in Tampere on 15 and 16 October 1999, acknowledged the need for harmonization of national legislation on the conditions for admission and residence of third country nationals. In this context, it has in particular stated that the European Union should ensure fair treatment of third country nationals residing lawfully in the territory of Member States and that a more vigorous integration policy should aim at granting them the rights and obligations comparable to those of citizens of the European Union. The European Council accordingly asked the Council to rapidly adopt the legal instruments on the basis of the Commission's proposals. The need for achieving the objectives defined at Tampere has been reaffirmed by the Laeken European Council on 14 and 15 December 2001. The Council also acknowledged the need for the harmonization of national legislation on the conditions for admission and residence of third-country nationals. In December 1999, the European Commission presented a proposal for an EU Directive on the right to family reunification 4 . After years of negotiations the text agreed by the Council in February 2003 was finally adopted on 22 September 2003 and it entered into force on 3 October $2003^{5}$.

Directive 2003/86/EC, the so called Family Reunification Directive, is the first major directive on legal migration adopted by the Council of Ministers after the Treaty of Amsterdam entered into force. Therefore, since 2006, the European Union has a regulation of family reunification of third-country nationals in the territory of the EU. Shortly after the Directive had been adopted by the Council, the European Parliament asked the Court ${ }^{6}$ to annul three provisions of the Directive: the last sentence of Article 4 (1) on the admission of children over 12 years of age, Article 4 (5) on the admission of children over 15 years of age and Article 8 on the waiting period. The Parliament deemed those provisions to be in violation of Article 8 and 14 ECHR. In its judgment of June 20067, the Court dismissed the action by the Parliament but used the opportunity to clarify that Directive 2003/86/EC grants a subjective right to family reunification to individuals and sets clear limits on the margin of appreciation of the Member States when making individual decisions concerning family reunifications ${ }^{8}$. The Directive lays down a set of rules governing the procedure for examination of applications for family

\footnotetext{
3 OJ C 340, 10 November 1997, 173-306.

${ }^{4}$ COM (1999) 638, OJ C 116 E, 26 April 2000, 66.

${ }^{5}$ L 251, 3 October 2003, 12.

${ }^{6}$ The European Parliament made use of its new competence for the first time to start legal action for annulment of a measure of secondary Community law. This new competence had been inserted by the Treaty of Nice on Article 230 EC Treaty.

${ }^{7}$ ECJ 27 June 2006, Case C-450/03 Parliament v. Council, (2006) ECR, I-5769.

8 The judgment illustrates the importance of the power granted to the Parliament by Article 230 Treaty as a means of supporting the rights granted by Community law to individuals, of clarifying the obligations of Member States and of enhancing respect for human rights and Community law by the Council and by the authorities of the Member States. The Court affirms that Article 4 (1) imposes precise positive obligations, with corresponding clearly defined individual rights, on the Member States, since it requires them, in the cases determined by the Directive, to authorize family reunification of certain members of the sponsor's family, without being left a margin of appreciation. This illustrates the important additional rights granted by the Directive to the family members mentioned in Article 4 (1): the spouse and minor children. Those rights go far beyond what has been guaranteed under Article 8 ECHR. The margin of appreciation allowed to Member States under Article 8 ECHR is restricted by the Directive to those situations where Directive explicitly preserves, "a
} 
reunification and for entry and residence of family members (Colacino 2004: 76). The personal scope of the Directive is stated in Article 3 (3) of the Directive which confines its scope of application to family members of third country nationals who are not EU citizens. In this regard, family reunification is applied in any case to members of the nuclear family, that is to say the spouse and the minor children and it is for the Member States to decide whether they wish to authorize family reunification for relatives in the direct ascending line, adult unmarried children, unmarried or registered partners as well as, in the event of a polygamous marriage, minor children of a further spouse and the sponsor. Where a Member State authorizes family reunification of these persons, this has to be made without prejudice of the possibility, for Member States which do not recognize the existence of family ties in the cases covered by this provision, of not granting to the said persons the treatment of family members with regard to the right to reside in another Member State, as defined by the relevant $\mathrm{EC}$ legislation.

The right to family reunification is exercised in proper compliance with the values and principles recognized by the Member States, in particular with respect to the rights of women and of children; such compliance justifies the possible taking of restrictive measures against applications for family reunification of polygamous households. Family reunification may be refused on duly justified grounds. In particular, the person who wishes to be granted family reunification should not constitute a threat to public policy or public security. The notion of public policy may cover a conviction for committing a serious crime. In this context it has to be noted that the notion of public policy and public security covers also cases in which a third country national belongs to an association which supports terrorism, supports such an association or has extremist aspirations.

\section{Family reunification in Albania.}

As we mentioned in the introduction, the aim of this study is to examine the procedures, the conditions and the beneficiaries of family reunification of migrants and refugees that are in Albanian territory and in particular the examination of Albanian Migration and Asylum Legislation. The new legislation is presented as a complete text related to the legal status of foreigners and refugees: it provides for substantial protection of family life, the requirements for family reunification (in particular sufficient housing for family members and resources to support them) and the time period within which the administration must act, the family members who are entitled to join a foreigner who has entered lawfully and is lawfully resident in Albania. However, this legislation has been subject to several criticisms, related to the contradiction that the concept of family member brings, the procedures and the large discretion given to the administrative authorities that are designated to implement the provisions, etc.

Protection of family life is stated in Albania legislations. The legal framework which deals with family reunification in Albania is composed of the Constitution of the Republic of Albania, Law No 9959, dated 18.07.2008 "On foreigners" and Law No 8432, dated 14.12.1998 "On Asylum in the Republic of Albania"9.

Constitution of Albania states that marriage and family enjoy special protection by the state: everyone has the right to get married and have a family; marriage and family enjoy special protection by the state ${ }^{10}$. Same protection to the family is guaranteed by other international legislations, ratified by Albania: everyone enjoys the right to marry and the right to have a family as provided by law and everyone enjoys the right to have her/his private and family life. In accordance with the Constitution, Albania recognizes the right of family reunification. However, family reunification is regulated but not defined by the legislation of Albania.

\section{a. Family Members}

Albanian legislation grants a subjective right to family reunification to the spouse and minor children of the sponsor who fulfill the conditions set by these legislations. In particular, Art. 2 of Law No 9959/08 of Albania is dedicated to "Family members". Family Members are considered: a) the spouse b) the minor children of the applicant and of his/her spouse

limited margin of appreciation for those States" (paragraph 62). The three clauses attacked by the Parliament in its action are examples of such exceptions (paragraph 97).

${ }^{9}$ Law No 8432, dated 14.12.1998 "On Asylum in the Republic of Albania" has amended Law No 9098 dated 03.7.2003 "On the integration and family of persons who have received asylum in the Republic of Albania".

${ }^{10}$ See Articles 53-54 of the Constitution of Albania, Art. 7 of Albania Family Code and Law No. 9062 dated 8.05. 2003. See in general on this argument OMARI - ANASTASI, E drejta kushtetuese, Tiranë, 2008; ANASTASI, E drejta kushtetuese e krahasuar: raste nga praktika kushtetuese dhe leksione për studentët e drejtësisë, Tiranë, 2009. KURTESH, E drejta kushtetuese, Prishtinë, 2004; ALIU, GASHI, E drejta familiare, Prishtinë, 2007. 
under 18; adopted children or children in custody, the mother or father of the minor children c) dependent direct relatives in the ascending line of the spouse or the sponsor.

So, in Albania the categories of family member are specified. As an extra condition, the legislation requires that the spouse and the children come to live together with the sponsor.

The first category mentioned is the sponsor's spouse. In the context of spouses, a remark should also be made on the position of polygamous marriages. Only one spouse can apply for family reunification and where the sponsor already has a spouse living with him in the territory of the host State, the host State concerned shall not authorize the family reunification of a further spouse (Mandro 2009: 16). The polygamous marriage is expressively forbidden by the Family Code of Albania as well (Mandro -Mecaj -Zaka -Fullani 2006: 32; Omari 2008, 55).

Albanian legislation does not provide for the right of family reunification for unmarried partners. It is important to note that this legislation does not confer the right of family reunification to those who are in a duly attested stable longterm relationship nor to those, whose sponsor is bound by a registered partnership. Considering the current reality, where many couples choose to live together in a stable relationship without getting married, this is to be seen as a move backward for the protection of personal rights of persons, especially for those persons who come from the European Union.

The category of minor children seems to have no complications. Albanian law provides that children must be under the age of 18 , while specifies that they have to be unmarried and depended on the sponsor in order to apply for family reunification, using the expression "minor children that have no proper family". It has to be said that there are no special rules for minor children aged over 12 or 15. The descendants are divided into three categories: the minor children of the sponsor and of the spouse, including adopted children; minor children including adopted children of the sponsor where the sponsor has the custody and the children are depended on him or her; the third category is similar to the second, with the difference that it concerns children of the spouse. The aim of this new legislation has been to avoid the differences between children born within the marriage, children born out of wedlock or from an earlier marriage or even adopted children. Another interesting remark concerns the age of majority. This age in these laws is specified to be 18 years old, while it was mentioned that the minor children should not be married. However, it is not specified whether reference has to be made to general rules of private law, or to the alien's law of the specific State. In addition, Community law on family reunification, for European citizens provides that children must be under the age of 21. This is not in accordance with the rules of family unit of European citizens but it is in line with the general regime of family reunification of third-country nationals that are in the territory of the EU, which states the majority age-limit to be 18 years old. In the case when the child arrives independently from the rest of his/her family, Albanian legislation guarantees (in practice) family reunification with both parents. The group of descendants is not enlarged by other descendants like nephews, adult unmarried children, children with handicap, etc. There is also a general obligation that applications by a child or his/her parents to enter a State for the purpose of family reunification are to be dealt with by the State in a positive, humane and expeditious manner ${ }^{11}$. This results in a clear emphasis on the need for national authorities to take into account the best interest of the child when deciding individual cases.

As regards relatives in the ascending line, it is specified that they can apply for family reunification if they are in direct ascending line of the sponsor (not of the spouse) when they are depended on the sponsor. It is not mentioned if they have to demonstrate that they do not enjoy proper family support in the country of origin. A remark should be made here on the wording of Art. 2 of the Albanian Law. It is specified that the relatives must depend on the sponsor and not on the sponsor or his/her spouse. It can, in practice, be a very important difference because the relatives must be depends on the sponsor and not on the income of the entire family.

Albanian law does not provide the right to family reunification for another category of family members. In some cases a reference is made to any other close member of the family, who may, under very strict circumstances, apply for family reunification, but only and exclusively where they are objectively unable to provide for their own needs, or there are special personal or humanitarian reasons. In fact, in these cases, Albania should facilitate family reunification and also social and occupational integration for this type of humanitarian cases.

A different situation is presented in Albania where Asylum law guarantees the right to asylum to the spouse, children under 18 years of age and to any other relative under the legal custody of the refugee, who has been granted asylum, where provided they reside together. The person above the age of 18 cannot be granted asylum by application of the principle of family unity in accordance with paragraph 1 of this Article, unless he/she is dependant of his refugee parents who have been granted asylum in the Republic of Albania. He/she should lodge an individual application in case

${ }^{11}$ Article 9 and 10 of the International Convention on the Rights of the Child. 
he/she desires to be granted asylum in the Republic of Albania. In case of divorce, separation or death of the refugee granted asylum, the family members who have obtained asylum in accordance to paragraph 1 of this article, shall continue enjoying asylum. The same applies to children enjoying asylum in accordance with the principle of family unity when they reach the age of $18^{12}$.

\section{b. Formal Conditions}

Based on the Migration legislation of Albania, non-nationals have the right to apply for a residence permit on the basis of family reunification if one of the family members is a non-national or a refugee, with a residence permit valid for not less than one year. With regard to the criteria of admission, the possibility of imposing a waiting period is recognized. Albania reserves the right to require the non-nationals to be lawfully present in their territory for a certain period of time, one year, before family members may be reunited with them under the terms of family reunification. Thus, it is limited to nonnationals who are residing lawfully in the host State and holding a residence permit issued by that host State for a period of at least one year ${ }^{13}$. Usually, host States are free to impose a "waiting period" before they allow family reunification. In Albania it is defined in one year, and not two or three years like in some European Union Member States. This excludes by definition seasonal workers, students and temporary workers. The legislations include refugees under the Geneva Convention but seem to exclude persons awaiting the decision on their asylum-claim as well as non-nationals who are authorized to reside in the host State on the basis of a temporary protection or persons who have applied for such a status $^{14}$. Minister of Public Order (MRP) is the responsible body for issuing residence permits and for addressing family reunification applications. MRP is the only authority that decides on the exclusion of family members of Albanian citizens or permanent residents while it is the competent institution that deals with work permits as well.

Regarding the administrative side of the family reunification procedure, the application must normally be made by the member's family and must be made whilst the family member is outside the territory of the host State concerned. Also, the family member must be in the possession of a visa or other prior written authorization of entry for the purpose of family reunification, and of valid travel documents. Clearly, identity documents and documents validating the existing family relationship must be produced. Other documents that should accompany the application concern the compliance with the conditions of minors, such as the documents confirming adoption or custody over minor children, the dependency of relatives in the ascending line and the absence of family support in the state of origin, etc. (Ikonomi 2011: 79). The legislation also mentions that the application for family reunification should be accompanied by documentary evidence of compliance with the conditions set by the legislations.

\section{c. Material conditions}

The host State requires evidence from the sponsor, such as stable and regular resources which are sufficient to maintain himself/herself and the members of his/her family; accommodation regarded as normal for his/her family; sickness insurance in respect of all risks normally covered for its own nationals in the host State concerning for himself/herself and his/her family members. The requirement of adequate housing is comparable to the Directive 2003/86/EC and to Regulation 1612/68 (and not to the directive 2004/38/EC). In particular, Albanian Legislation requires that accommodation must meet general health and safety standards in force. The definition of the housing condition in Albania legislation has been amended, but has not really changed in its substance. The resources must be "stable and regular" but not excluding this way persons who live on their capital. The resources are calculated by both the applicant and the spouse and are evaluated by reference to their nature and regularity. The host State has much more discretion to decide if the resources requirement is met. The reason for this condition is that the sponsor and his family are able to maintain and accommodate themselves without recourse to public funds. It is not specified however in these legislations the level of income required. For instance, the level of income support is considered an acceptable minimum standard of support, but each case is judged individually, depending on individual needs. Sometimes the requirement is geared towards the level of social assistance benefits, but the specified amount of income is dependent on the individual circumstances.

\footnotetext{
${ }^{12}$ Article 6 of Law No 8432 on Asylum in the Republic of Albania. See IKONOMI, E drejta migratore, Tiranë, 2011, 79.

${ }^{13}$ See Article 32 par. 1, (b) of Law No 9959.

${ }^{14}$ Article 6 of Law on Asylum in the Republic of Albania.
} 
Other conditions mentioned by the legislation are facultative, which means that the applicant only has to come up with the documentary proof if the host State in question requires so. This is specified in the Decisions of the Council of Minister ${ }^{15}$ and the purpose of these conditions is to make sure the sponsor can host members of his family and that those persons will not become a financial burden for the host State.

However, the host State may refuse to allow the entry and residence of family members on grounds of public policy, domestic security and public health. It seems to imply that the burden of proof lies with the applicant for entry. The host State may also withdraw or refuse to renew a family member's residence permit for these reasons. When taking the decision, the host State is obliged to consider the severity or type of offence against public policy or public security committed by the family member, or the danger that are presented by the person. The practice of these States is hard to establish on the basis of the law and regulations or decisions, as their formulations are rather vague. In any case the legislation of Albania requires a family member who wants to obtain a visa for family reunification to prove that he/she has not been sentenced for having committed a crime ${ }^{16}$. Therefore, he/she must hand over a criminal record, issued by the country of residence for the previous years. Article 8 of Law 9959/08 of Albania specified that membership of an organization which has "anti-constitutional" elements or supports terrorism is one of the grounds of refusal. This new provision enables the authorities to automatically refuse the application of a family member if he or she constitutes a threat to the public order. According to the new rules, the decisions have to be better motivated, and personal circumstances have to be taken into account more explicitly than before.

The host State may reject an application for family reunification, withdraw, or refuse to renew a family member's residence permit, if the sponsor and his/her family member(s) do not live or no longer live in a real marital or family relationship. The host State requires a real marital or family relationship with spouses who apply for reunification. The residence permit is refused or withdrawn if the marriage was conducted for the sole purpose of obtaining a residence permit ${ }^{17}$. According to the law, the authorities are competent to assess whether the marriage for which a residence permit is requested or issued, is a marriage of convenience. The marriage has been estimated as a marriage of convenience by legislation of Albania when it is impossible for the spouse to live and communicate together, or one spouse does not know the personal details of the other. How and on which criteria this assessment is carried out or what powers the authorities have is not specified.

\section{d. Legal Position of Family Members}

This section examines the rights granted on reuniting family members of the foreigner in the territory of Albania. The rights included in this section are the right of residence; the right to take up an employment as a worker or as a selfemployed person; the right to education and the right to social advantage. Albania legislation grants the basic rights that family members can claim. Article 33 par. 2 of Law No 9959 specifies that all family members enjoy the same rights and obligations as the sponsor does. Once the host State has accepted the application for family reunification it should make the effective exercise, i.e. the entry into the territory, relatively easy. The administrative hurdle should, at that point, be as low as possible and without costs.

The right of residence is the most obvious right to be conferred on family members, apart from the right of entry. All legal instruments explicitly mention this right even though in different wordings: "the right of residence is granted to", "have the right to remain permanently in the territory of", "be issued with a residence document" etc. The admission is, however, limited to the actual cohabitation with the sponsor. The duration of the first residence permit is at one year. An important question in this respect is in how far the right of residence of the family members is dependent on the sponsor. Can the family members remain in the host State after a divorce (in the case of spouses), or reaching the age of adulthood (in the case of descendants) etc.? In case of divorce or death of the sponsor, the family member is not entitled to the residence permit unless a child is born and the spouse has the custody or where the family member has a previous residence permit of two years. However, after five years of residence they are entitled to apply for an autonomous residence permit (Art. 33). So, it is not provided that family members, after the application for family reunification are entitled to remain in the territory until three years fulfilling the conditions for issuing a personal permit for permanent residence. Usually, in the Member States of the European Union, the family members, are entitled to remain in the territory of the host State even after the death of the sponsor, or in case of divorce. As seen, in Albania the

\footnotetext{
15 See, for example, Decision No 439/2000, Decision No 532/2001 etc.

${ }^{16}$ Artt. 8 and 35 of Law No 9959/08.

17 See paragraph 2 of Article 34 of Law No 9959.
} 
situation is presented differently. Besides the right of residence, the family members, or at least the members of the nuclear family can claim a set of rights. The most important one is the right to take up an employment. The latter is clearly an accessory to the right of residence of family members. Therefore, it is limited or even absent when the right of residence is limited. It appears to be in the interest of the host State to allow persons, legally residing in their territory to take up an employment. It is important to note that this right is granted in Albania.

Family members, who are accepted for the purpose of family reunification, are treated in the same way as the sponsor is, in accordance to the human rights and fundamental freedoms and international agreements ratified by the Republic of Albania, respecting the principle of reciprocity, non-discrimination, like Albanian citizens. This is mentioned as a general principle in Art. 2 of the Albanian law (Ikonomi 2011: 129). They have the right of free movement in the territory of these States, expressively mentioned in the Albanian legislation.

A last remark regarding family member's rights must be made. Usually, Community law for EU citizen or thirdcountry nationals, grants family members the right to access to education (primary or secondary) and vocational training and the social advantage. This kind of rights in Albania are not explicitly granted.

\section{Conclusions and recommendations}

The right to family life is very important for every person, including migrant workers and refugees. The right to respect family life and, in particular, family reunification, is among the fundamental rights protected by Albanian legislation. The right to live with one's close family results in obligations for the host State which may be negative, when the host State is required not to deport a person, or positive, when it is required to allow a person enter and reside in its territory. There are some general principles applicable to family reunification. The extent of the host State obligation to admit to its territory relatives of settled immigrants varies according to the particular circumstances of the persons involved and the general interest. As a matter of well-established international law and subject to its treaty and agreement obligations, a State has the right to control the entry of non-nationals into its territory.

In general, these principles are applied in the Republic of Albania as well. However, it is clear that family reunification, as in other countries, is a political issue. One might argue that family reunification in Albania, as analyzed in this paper, is perceived as in the old Europe, where the phenomenon of immigrants and mobility seemed to raise "feelings of enmity". Family reunification is generally believed to account for a large proportion of immigration. This is not the case of Albania, where the phenomenon of immigration is not so spread. Moreover, Albania is still considered to be a country of large emigration. Family reunification is essentially about settling down and developing roots in a new environment.

This study has shown that progress has been achieved and many efforts have been made on the way to streamlining this country' policy towards a more rapid accommodation of EU policies and legislation. Albania has adopted, in this context, new legislation on migration and has adopted new rules on family reunification. It is important to note that there is harmonization with European Union law in this field. This legislation, in principle has created a legal framework, according to the European Union rules on family reunification, but it is not a complete legal framework and still remains a low standard of protection of migrants and their family members. This low standard of protection of "family life" and the rights conferred to the family member is probably due to the fact that Albanian legislation only set minimum standards which have to be respected. The comparison of Albanian legislation on family reunification with that of the Member States of the European Union has concluded that there are similarities between these legislations but there are a lot of differences as well. Albanian legislation is presented now more complete, reliable and more "in line" with the European standards even that the progress has been slower and less substantial than expected. Moreover, the formulation of the provisions of Albanian laws is not so articulated. In particular, the legislation on migration is formulated as a general obligation for the State to allow family reunification without specifying in detail which forms it should take.

In conclusion it can be recommended that the level of protection of family life in these instruments should be significantly higher than the present one. Many flexible elements should be introduced to facilitate the process of family reunification and to force the protection of the rights of family members. In particular, the unmarried partner must be included into the category of family member; to the family member must be granted the right to take up an employment as well as other social rights.

\section{References}

Adinolfi A., (2005) "La libertà di circolazione delle persone", in G.Strozzi, (a cura di) Diritto dell'Unione europea, Torino, 69-78. 
Aliu A., Gashi H., (2007) E drejta familiare, Prishtinë.

Anastasi A., (2009) E drejta kushtetuese e krahasuar: raste nga praktika kushtetuese dhe leksione për studentët e drejtësisë, Tiranë.

Bariatti S. (2007) La famiglia nel diritto internazionale privato comunitario, Milano.

Barret G., 2003 "Family matters: European community law and third-country family members", Common Market Law Review: 377-390.

Bellagamba G. and Cariti G., (2005) La disciplina dell'immigrazione, Milano.

Bergern. B, (2000) La politique européenne d'asile et d'immigration. Enjeux et perspectives, Bruxelles.

Boschiero N., (2007) "Les unions homosexuelles à l'épreuve du droit international privé italien", Rivista di diritto internazionale, 1: 50-59.

Brinkmann G., (2002) "Family reunification of third-country nationals: access of family members to social protection benefits", European Journal of migration and law: 325-341.

Caggia F., (2006) Famiglia e diritti fondamentali nel sistema dell'Unione Europea, Roma.

Calamo Specchia M., (2006) "Il Conseil Constitutionnel e la protezione dell'immigrato: la difficile cittadinanza dei diritti costituzionali "deboli" tra accoglienza e integrazione", Diritto Pubblico Comparato ed europeo, 11: 1580-1587.

Campiglio C., (2008) "Il diritto di famiglia islamico nella prassi italiana", Rivista di diritto internazionale privato e processuale: $43-49$.

Caracciolo DI Torella E.- Masselot A., (2005) "Under construction: EU family law", European Jornal Law: 38-42.

Carlier J.-E.Guild, (ed.) (2006) L'avenir de la libre circulation des personnes dans l'UE. Analyse de la directive 2004/38 du 29 avril 2004 relative au droit des citoyens de circuler et de séjourner librement, Bryulant-Bruxelles.

Cellamare G., (2006) La disciplina dell'immigrazione nell'Unione europea, Torino.

Cholewinsky R. - Peruchoud R.- MacDonald E., (2007) International migration law. Developing paradigms and key challenges, The Hague.

Cholewinsky R., (2002) "Family reunification and conditions placed on family members: Dismalting a fundamental right", European Journal of migration and law: 35-44.

Colacino N., (2004) "Il diritto al ricongiungimento familiare e la disciplina introdotta dalla Direttiva 2003/86/CE", Saulle M.R., (a cura di) L'Europa tra costituzione asilo e immigrazione, Napoli.

Condinanzi M., Lang A., Nascimbene B., (2006) Cittadinanza dell'Unione e libera circolazione delle persone, Milano.

Costello C., (2009) "Metock: Free movement and "Normal Family life" in the Union", Common Market Law Review: 607-608.

Craig, p., de burga, (2011) eu, text, cases, and materials, Oxford.

Currie, S. (2009) "Accelerated Justice or a step too Far? Residence rights for non EU-family Members and the Court's Ruling in Metock", European Law Review: 324-325.

Di Pascale A.- Pastore M., (2007) "Il recepimento delle direttive sul ricongiungimento familiare e sui soggiornanti di lungo periodo", Diritto, Immigrazione e cittadinanza, 1: 16-23.

Giubboni S.-G.Orlandini, (2007) La libera circolazione dei lavoratori nell'Unione europea, Torino.

Groenendijk K.,Fernhout R.,Van Dam D.,Van Oers R.,Strik T.,(2007) The family Reunification Directive in EU Member States, Nijmegen. Groenendijk K., (2004) "Legal concepts of integration in EU migration law", European Journal of Migration and Law, 2: 119-124.

Guild E.- Harlow C. (2001), Implementing Amsterdam. Immigration and Asylum Rights in EC law, Oxford.

Guild E.- Niessen J., (1996) The developing immigration and asylum policies of the European Union, Kluwer Law International.

Guild E., (2004) The legal elements of European Identity - EU citizenship and Migration Law, Kluwer Law International.

Hailbronner K., (2007) "Free movement of EU nationals and Union citizenship", Cholewinski R.,- R.Perruchoud-E. MacDonald, (ed.) International migration law, The Hague: 320-332.

Ikonomi L., (2011) E drejta e migracionit, Tiranë.

Lang A.-B.Nascimbene, (2007) "L'attuazione in Italia della direttiva 2004/38/CE sulla libera circolazione dei cittadini dell'Unione europea", Diritto, immigrazione, cittadinanza, 2: 3-10.

M.Di Filippo, (2008) "La libera circolazione dei cittadini comunitari e l'ordinamento italiano: (poche) luci e (molte) ombre nell'attuazione della direttiva 2004/38", Rivista di diritto internazionale, 425-430.

Mandro A., (2009) E drejta familjare, Tiranë.

Mandro A., Mecaj V., Zaka T., Fullani A., (2006) E drejta familjare, Tiranë.

Missorici M.-C.Romano, 1998 "Libertà di circolazione e soggiorno: i cittadini degli Stati terzi tra cittadinanza europea e politica delle migrazioni", Rivista internazionale dei diritti dell'uomo, 11: 44-48.

Omari L.-A.Anastasi, (2008) E drejta kushtetuese, Tiranë.

Omari S., (2008) E drejta familjare, Tiranë.

Pallaro P., (2001) "Coppie di fatto e ricongiungimento familiare nell'ordinamento comunitario: un nuovo indirizzo della Corte di giustizia?", Diritto comunitario e degli scambi internazionali: 261-265.

Peers S., (2005) "Key legislative developments on migration", European Journal of Migration and Law: 265-282.

Sanna C., (2006) "La direttiva 2004/38/CE relativa al diritto dei cittadini dell'Unione e dei loro familiari di circolare e soggiornare liberamente nel territorio degli Stati membri", Rivista di diritto internazionale privato e processuale, 42: 1167-1178.

Sirianni G.,(2004) I/ diritto degli stranieri all'unità familiare, Perugia.

Villani U., (2011)n/stituzioni di diritto dell'Unione europea, Bari. 